\title{
TEXTUAL ENHANCEMENT: THE EFFICACY OF PROMOTING NOUN PHRASE ACQUISITION
}

\author{
Mira Shartika, Mazroatul Ishlahiyah \\ UIN Maulana Malik Ibrahim Malang \\ shartika@uin-malang.ac.id, mazroatul@uin-malang.ac.id
}

\section{Abstract}

This study investigated the improvement of students' abilities in identifying forms of noun phrases through textual enhancement, the difference in results between the high and low achievers in identifying forms of noun phrases through textual enhancement, and the relationship between textual enhancement and the ability of students who have high and low grades in identifying forms of noun phrases. The quantitative design was applied in order to obtain information. The project involved 44 EFL learners taking Intermediate English Grammar subject in one of Islamic universities in Malang, Indonesia. The participants were divided into 2 classes consisting of high and low achievers. The high achievers were the experiment group, and the low achievers were the control group. The results revealed that there was significant difference in the students' achievement in noun phrase acquisition between those who were taught by using textual enhancement (experimental group) and those who were taught by not using textual enhancement (control group). Second, there was significant different achievement between the high achievers and the low achievers of control and experimental group in learning noun phrase. Finally, there was an interaction found between Textual Enhancement (TE) and students' initial abilities (high achievers and low achievers).

Keyword: Textual Enhancement, Noun Phrase, high achievers, low achievers

\section{INTRODUCTION}

There has been a debate among researchers about the significance of learning grammatical rules or understanding the language rules naturally when someone learns a foreign language. Some academics (Ellis, 1994; Krashen, 1982; Long \& Robinson, 1998) oppose learning the rules of language specifically as grammar will naturally be mastered when language is learned. This is then supported by the emergence of the Communicative Language Teaching (CLT) approach that focuses on the communicative way of learning foreign languages, for example English. This approach highlights the understanding of meaning and fluency of language in oral and written form. The accuracy of understanding 
the form and rules of language should not be prioritized based on this approach. Yet, some language learners find it difficult to understand and apply grammar, and ultimately affect the fluency in using English as a means of communication. Therefore, according to Long (1985), although fluency in language is a top priority in language learning, an introduction to language structure also needs to be considered so that language learners can apply it when communicating in English.

Collin (2006) supports this by initiating Focus on Form (FonF), one approach to learning English that rejects the assumption that grammar can be effectively learned through communication activities. This approach directs language learners to observe several language features, including verbs or paragraph arrangements that appear naturally, incidentally, or periodically when students try to complete communication activities in task-based learning (Harmer, 2007). Consequently, Alshadan (2011) suggests one effective way to learn grammar, which is providing a visualization of the structure of language in the text called textual enhancement. Thickening, italicizing, or giving color to the pattern of language structure is commonly used to familiarize students with the language forms. The aim of this strategy is that students can explicitly see the patterns of language structure.

Therefore, employing a textual enhancement (TE) in EFL class is significantly needed especially for EFL learners in English Department in one of Islamic Universities in Malang, Indonesia to learn the form of noun phrase (NP). NP has many forms that makes it challenging to learn. In relevance to this, this study is aimed to investigate the improvement of students' abilities in identifying forms of NP through TE, the difference in results between students who have high grades and students who have low grades in identifying forms of NP through TE, and the relationship between TE and the ability of students who have high grades and low grades in identifying forms of NP.

\section{THEORETICAL FRAMEWORK}

In the history of second/foreign language teaching, some researchers apply three main approaches, including focusing on meaning, focusing on one language pattern, and focusing on several language patterns (Long \& Robinson, 1998). Further, there is only one of several approaches that encourages students to "pay attention", where this approach focuses on the form/pattern of the language. In this approach, language acquisition is considered a gradual accumulative process of teaching. Therefore, language learners learn each part of the language separately and gradually. For example, the teacher breaks up language into rules of grammar and vocabulary. Each rule is taught separately from the others. Students, then, are asked to synthesize these two language components to communicate in a second/foreign language. They are also encouraged to enter the vocabulary they learn into sentences using grammar rules that have been studied previously (Long \& Robinson, 1998).

There are several methods that emerged as a result of this approach such as the Grammar Translation Method. This method began in the sixteenth century with a focus 
on teaching grammar. The purpose of this method is to teach students to read foreign language literature. The Grammar Translation Method claims that when language learners learn grammar from the target language, they become able to read and write in a foreign language. In addition, second/foreign grammar knowledge increases grammar knowledge of the first language and, therefore, improves written and oral communication in the first language. As a result, the focus at that time was on teaching and memorizing grammar rules and translating from L1 to L2 and vice versa (Larsen-Freeman, 2007).

In the mid-nineteenth century, other methods appeared by a focus on form approaches and inspired by behavioral psychology and structural linguistics. This method is called the Audiolingual Method. Language learning is considered as a process of forming habits through repetition, imitation and reinforcement. Therefore, language learners learn grammar through analogy rather than analysis. In addition, the teacher does not need to teach explicit grammar. Language learners are expected to gain grammatical knowledge through practice (Larsen-Freeman, 2007).

However, the problem with focusing on the form approach with the synthetic method is that it does not allow students to achieve the use of the target language form as the original instructor (Long \& Robinson, 1998). Focus on forms/patterns refers to attracting students' attention to linguistic elements when they appear accidentally in a lesson whose main focus is on meaning or communication, while the focus on some forms/patterns is linked to traditional teaching about grammar points in separate lessons (Long, 1985). The focus on forms/patterns stems from the assumption of a degree of similarity between the mastery of the first and second languages which has two processes, both of which are based on exposure to comprehensive inputs arising from natural interactions. However, it is also assumed that there are significant differences in the two processes, that exposure is not enough to enable learners to get a lot from second language grammar, and that these shortcomings need to be compensated by focusing students' attention on grammatical features.

The focus on some forms/patterns, conversely, is based on the assumption that learning in a second/foreign language class stems from a general cognitive process, and thus requires skill learning; hence, characterized as a 'skills learning approach', consisting of three stages. The first stage is to provide understanding of grammar in various ways (including explanations in the first language (L1), and showing the difference between L1 and the second language (L2). Second, training that involves the use of grammar in both non-communicative and communicative activities for understanding and the last is to provide frequent opportunities for communicative grammar to promote automatic and accurate use (Sheen, 2002).

Before introducing increased input, Smith (1993) presents awareness rising as an effort to solve second/foreign language teaching/learning problems that arise in focus on the form approach. Increased awareness means that language teachers try to increase language learners' awareness of new target forms. Smith further states that even if language learners pay attention on improved target forms, this does not guarantee that 
they will be able to internalize forms. In addition, many criticize this term for the lack of theoretical support for the relationship between conscious processes and inputs. Therefore, Smith (1993) exchanges terms for increased awareness with increased input that can be controlled by the teacher. The role of increasing input is to make several forms of second/foreign languages more prominent to attract the attention of language learners to them.

In fact, Smith (1993) divides salience into two types: external salience, whereby the teacher or researcher can manipulate text, and internal salience that refers to students' thoughts or mental states that are changed by input. Han, Park \& Combs (2008) suggest several factors that can increase salience for language learners. These factors are the failure of understanding, current inter-language knowledge of learners, learner bias for meaning above form, differences in learners, and learner's first language. However, this research will only focus on how to enhance the first salience, which is external salience through the use of several improvement techniques that can be used by teachers in teaching grammar.

Textual enhancement (TE) is an external form of increasing input, where the attention of students is directed at the linguistic form through manipulation of certain aspects of the text to make it easy to notice. Because this technique highlights the correct form of input, this is a form of positive input increase. TE is also an implicit form of increased input because it seeks to attract the attention of learners to form the language pattern while the focus remains on meaning (Nassaji \& Fotos, 2011). Further, Nassaji \& Fotos argue that TE is done to improve the salience of input in written or oral texts with the aim of facilitating learners to pay attention on targeted forms and to increase their understanding on grammar.

Additionally, TE is an external form of increasing input, where students' attention is drawn to the linguistic form through physically manipulating certain aspects of the text to make it easily noticed (Smith, 1993). There are several characteristics of TE. First, TE is the positive form of increasing input. Second, TE is an implicit form of input increase, where TE tries to make prominent forms in input; however, it does not involve any explicit instructions. Finally, the meaning and use of TE must be clear to learners so that the linguistic characteristics can convey meaning.

Furthermore, TE can be used with written and oral texts. In written text, this can be done by typologically highlighting the specific target words embedded in the text with text modifications, such as underscores, bold letters, italics, capital letters, capital letters, color codes, or a combination of these. It can also be used with spoken text. Oral input can be made more real through various intonational and phonological, manipulations, such as additional stress, intonation, or repetition of targeted forms, or even through movements, body movements, or facial expressions (Nassaji \& Fotos, 2011). In textual improvement, students must read the text for meaning. Therefore, it is very important for teachers to use strategies that can keep students' attention to the message. This can be achieved by using various forms of post-reading activities. When designing text that is enhanced text, the following steps must be taken: (1) choose a specific grammar point that 
you think your students need to pay attention on, (2) highlight the feature in the text using one of the TE strategies or combined techniques, (3) make sure you do not highlight lots of different shapes because they can distract the students from the meaning, (4) use strategies to keep students' attention on meaning.

There are several previous studies that investigated the influence of TE on students' learning. Sarboland's study resulted in the efficacy of underlining and thickening words in bringing students' attention and intake on English past tense (2012). However, the choice of TE format was not effective because different types of TE have different effects on notification and target structure intake. Meanwhile, Ayiewbey (2013) examined the effects of textual improvement on past tense learning in English. The results showed that both bold and italics improve students' learning about shapes, even though thick-faced groups show better performance than groups that are given italicized words.

On the other hand, Ghorbani \& Nezamoshari'e (2012) conducted a study on EFL student's grammar achievement. The results contended that there was significant difference between the high achievers in the experiment class regarding their grammar achievement. It means that the high achievers took advantages of learning than the lower achievers.

In addition, Nahavandi \& Mukundan (2013) examined the impact of increased text input and the presentation of explicit rules on the basic intake of EFL students of Iranian students from simple past tense. The results showed that there were significant differences between the control and the experimental group. Thus, there was a significant effect of TE on the basic EFL intake of Iranian students from simple past tense.

Furthermore, Torkabada \& Fazilatfar (2014) examined the effects of Textual Enhancement (TE) and Input Processing (IP) as two types of treatments compared to Traditional Instruction (TI) as a control context to meet the objectives of focusing on simple forms of present and past tense. This reveals the difference between the three groups' performance in terms of accurate use of subjects from selected grammar points. The results showed that both treatments (TE \& IP) were more effective than Traditional Instructions, but TE and IP were not significantly different from one another.

Moreover, Wicaksono (2015) examined the effects of TE on passive voice achievement, which resulted in a significant effect on the teaching of passive voice to secondary school students. Finally, Mehrdad (2015) investigated the effects of TE on verbal learning for male students in secondary schools. The results showed that the experimental group outperformed the comparison group and the application of TE increased the verbal acquisition of EFL students. From previous studies, several researchers found that textual improvement was effective in learning and teaching the form of English target forms, while other studies found that textual improvement had insignificant effects on learning the target form of English. Thus, this study aims to verify the effect of TE in learning English to identify forms of noun phrase (NP), to examine whether there is significant different achievement between the high and low achievers of 
control and experimental group in learning NP, and to investigate the effect of TE on the initial abilities of both types of students.

\section{METHOD}

This research, attempting to find the effect of textual enhancement on students' learning noun phrase on reading texts, used quasi-experimental design since the researchers had no access in assigning the class (Latief, 2012). The design was elaborated with factorial design because the researchers attempted to see the effect of two independent variables, namely active and attributive independent variables. The active independent variable of this research was Textual Enhancement, and the attributive independent variable was students' initial ability, i.e. high and low achievers. The main purpose for using a factorial design was to see if the effect of treatment is consistence across different initial of students, high or low achievers. The simple factorial design can be seen in Table 1 below.

Table 1. Simple Factorial Design $(2 \times 2)$

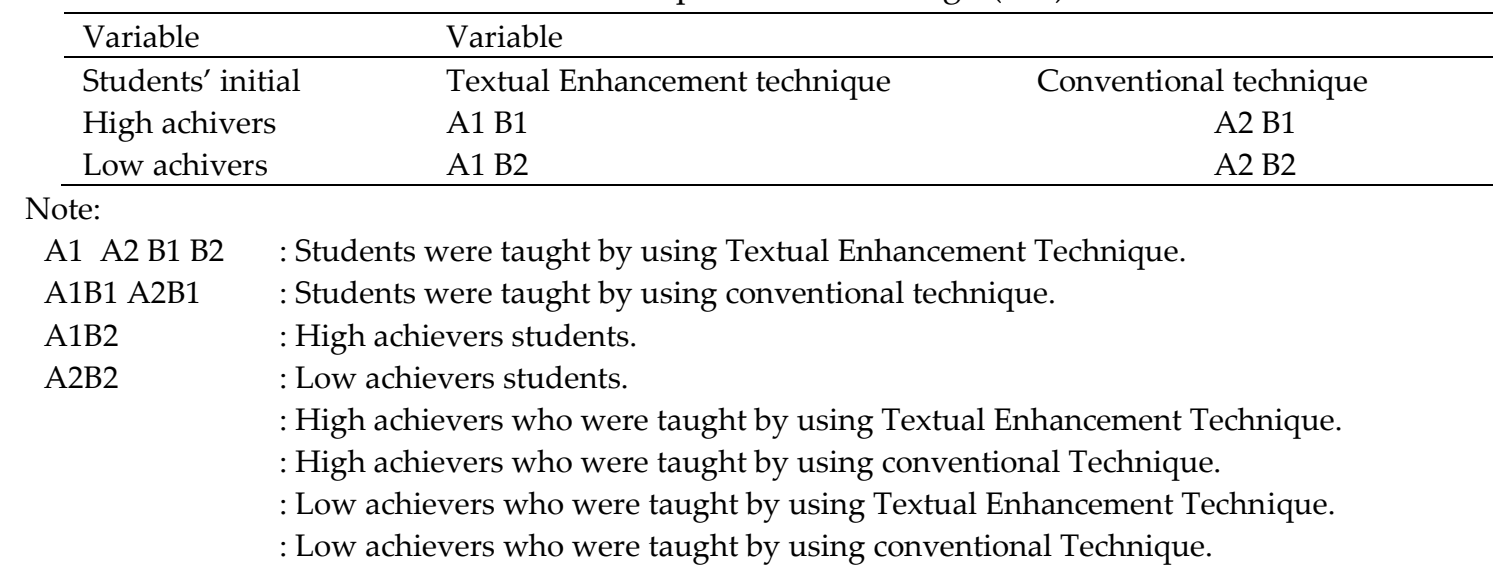

The study was conducted in one of Islamic universities in Malang about the use of noun phrase. The subjects of the study were 44 third semester students taking Intermediate English Grammar class. The students were divided into two groups including high and low achievers. The students were chosen as the accessible population based on some considerations: 1) they were equipped with knowledge about Basic English Grammar, the prerequisite course of Intensive English Grammar, 2) the objectives of the research matched with the university syllabus; therefore, it did not interrupt the class' activities.

The total number of this research population was 44 students, which were divided into two classes, experimental and control group.

Table 2. Students' basic information

\begin{tabular}{lll}
\hline & Experimental Class & Control Class \\
\hline Gender & Male $=7$ & Male $=8$ \\
& Female $=15$ & Female $=14$ \\
\hline
\end{tabular}




\begin{tabular}{lll}
\hline Prerequisite Course & Basic English & Basic English \\
& Grammar & Grammar \\
\hline Course Undertaking & Intermediate & Intermediate \\
& English Grammar & English Grammar \\
\hline
\end{tabular}

As had been mentioned in this research, textual enhancement (TE) on reading text was studied in this study. The texts used were recount texts, whose genre was introduced in semester 1. By using the same materials, the experimental group was taught using textual enhancement, where some of its words were enhanced and the control group was taught using conventional technique. At the first meeting both groups were given pretest and at the last meeting they were given posttest. In the second to third meeting they were given the treatment. The treatment was only given in two meetings because noun phrase was only taught and discussed in four meetings in IEG class. In addition, there were other materials involving adjectives, prepositions, negation, clause types, comparatives and superlatives, and coordination, to discuss in IEG class. If the treatment was done in more than two meetings, it will interrupt the class' activities.

Table 3. The Schedule for Experimental and Control Group

\begin{tabular}{|c|c|c|}
\hline Meeting & & Experimental Reading \\
\hline 1 & Pretest & Pre-test \\
\hline \multirow{3}{*}{2} & \multirow{6}{*}{ Treatment } & Fishing \\
\hline & & A Thief \\
\hline & & My Holiday \\
\hline \multirow{3}{*}{3} & & Travelling Abroad \\
\hline & & My Rainforest Adventure \\
\hline & & My First Time in Yogyakarta \\
\hline 4 & Posttest & Post-test \\
\hline
\end{tabular}

The two groups experienced the same process of reading and the same target form. The treatment for experimental group was done in two meetings, while the first meeting was used for the pretest and the last meeting for the posttest. There were three stages in the teaching or treatment process, including exploration, practice, and confirmation. In the first stage, the students were stimulated with some questions in NP. After that, in the elaboration stage, the students were given three texts with some highlighted words as a practice of TE. In this stage, the students were asked to read the text silently and pay attention on the highlighted words, and discuss the text in groups. Finally, the students were asked to explain the texts and the forms of NP in the confirmation stage.

The control group receives the same treatment, but in a conventional way, which was also done in two meetings. First, the students were stimulated with some questions related to the forms of NP. Then, the teacher gave them several texts without enhanced words and they were asked to have discussion in groups. During group discussion, they were asked to make sample sentences containing noun phrases. At the last stage, the students were given several questions regarding the reading passages and forms of NP. All activities done in both classes are summed up in Table 4 below. 
Table 4. Detailed Activities in the Experimental and the Control Groups in the second \& third

\begin{tabular}{|c|c|c|}
\hline \multirow{2}{*}{ Stages } & Activities & \\
\hline & Experimental Group & Control Group \\
\hline Opening & $\begin{array}{l}\text { 1. Greeting } \\
\text { 2. Affirming the day's topic } \\
\text { 3. Activating students' background } \\
\text { knowledge about NP }\end{array}$ & $\begin{array}{l}\text { 1. Greeting } \\
\text { 2. Affirming the day's topic } \\
\text { 3. Activating students' background } \\
\text { knowledge about NP }\end{array}$ \\
\hline \multicolumn{3}{|l|}{ Main activities } \\
\hline Exploration & $\begin{array}{l}\text { 1. Stimulating students by giving some } \\
\text { questions about NP }\end{array}$ & $\begin{array}{l}\text { 1. Stimulating students by giving some } \\
\text { questions about NP }\end{array}$ \\
\hline Elaboration & $\begin{array}{l}\text { 1. Giving the texts to students with some } \\
\text { enhanced words } \\
\text { 2. Asking students to read the text silently } \\
\text { and paying attention on } \\
\text { the function, structure and language } \\
\text { features of NP } \\
\text { 3. Asking students to work in groups to } \\
\text { discuss the forms of NP }\end{array}$ & $\begin{array}{l}\text { 1. Giving the texts to students } \\
\text { 2. Asking students to read the text silently } \\
\text { and pay attention on the } \\
\text { function, the structure and language } \\
\text { features of NP } \\
\text { 3. Asking students to work in groups to } \\
\text { discuss the forms of NP } \\
\text { 4. Asking students to make new sentences } \\
\text { containing NP }\end{array}$ \\
\hline Comfirmation & $\begin{array}{l}\text { 1. Asking students about the forms of NP } \\
\text { that they have learnt from the text. } \\
\text { 2. Giving feedback to students }\end{array}$ & $\begin{array}{l}\text { 1. Asking students to answer the questions } \\
\text { related to NP } \\
\text { 2. Giving feedback to students }\end{array}$ \\
\hline \multicolumn{3}{|l|}{ Closing } \\
\hline $\begin{array}{l}\text { Extension and } \\
\text { follow-up }\end{array}$ & $\begin{array}{l}\text { 1. Reviewing what students have learnt } \\
\text { about NP } \\
\text { 2. Closing }\end{array}$ & $\begin{array}{l}\text { 1. Reviewing what students have learnt about } \\
\text { NP } \\
\text { 2. Closing }\end{array}$ \\
\hline
\end{tabular}

To gain the data for this study, some instruments were used. Since the data was collected from students' score in measuring NP to know the significant effects of the treatment. The researchers needed a treatment to measure it, which was represented by students' score. Ary, et.al. (2010) assert that the test is an evaluable measuring instrument for educational research. Besides the test, the researchers used documentary file of students' score to examine which group of students gain better in learning English.

Table 5. Instruments in Taking the Data

\begin{tabular}{lllll}
\hline Instrument & Data & $\begin{array}{l}\text { Source of } \\
\text { data }\end{array}$ & Variables & Analysis \\
\hline Multiple choice & $\begin{array}{l}\text { The students' } \\
\text { scores }\end{array}$ & $\begin{array}{l}\text { The } \\
\text { students }\end{array}$ & Students' ability in NP & $\begin{array}{l}\text { Scoring the students' target } \\
\text { form based on the number } \\
\text { of correct answers }\end{array}$ \\
\hline Documentary & $\begin{array}{l}\text { The students' } \\
\text { achievement }\end{array}$ & $\begin{array}{l}\text { The } \\
\text { students }\end{array}$ & $\begin{array}{l}\text { Students' achievement } \\
\text { in the test }\end{array}$ & $\begin{array}{l}\text { Measuring the post test on } \\
\text { high and low achievers }\end{array}$ \\
\hline
\end{tabular}

The test used in this research was achievement test. Ary, et.al. (2010) state that achievement test is used to measure what individual have learned. The type of the test used to gain the students' score in NP was an objective test. Objective test was chosen based on consideration that it is easy to score. The test was made by the researchers and conferred with the lecturers in both IEG classes. Both tests including pretest and posttest 
were used to get students' score as the primary data to be compared. The test was about NP consisting of 20 items in the form of multiple choices. To get the score, the researchers used the pattern as follows.

\section{The Students' Score $=\underline{\text { Right answers }} \times 100$}

Total answers

Furthermore, the result of the data analysis was used to show whether there was enough evidence or not to reject null hypotheses (Ho). The hypotheses were formulated in the followings.

\section{Hypotheses 1}

$\mathrm{H}_{0}=$ There is no effect of textual enhancement EFL students' learning noun phrase. $\mathrm{H}_{1}=$ There is an effect of textual enhancement EFL students' learning noun phrase. Hypotheses 2

$\mathrm{H}_{0}=$ There is no significant different achievement between students with the high achievers and the low achievers in learning noun phrase.

$\mathrm{H}_{1}=$ There is significant different achievement between students with the high achievers and the low achievers in learning noun phrase.

\section{Hypotheses 3}

$\mathrm{H}_{0}=$ There is an interaction between the Textual Enhancement and students' initial (high achievers and low achievers) in learning noun phrase.

$\mathrm{H}_{1}=$ There is no interaction between the Textual Enhancement and students' initial (high achievers and low achievers) in learning noun phrase.

The consideration for rejection and acceptance of the null hypotheses is a level significance .050, which is considered acceptable in the field of education. If the probability level or the significant level is or less than $.050(\mathrm{p}<.050)$, it means that there is significant difference between the two groups and the null hypothesis is rejected. In other words, there is an effect of TE on students' learning NP. If the probability level or the significant level is greater than .050 ( $\mathrm{p}>.050)$, it means that there is no effect of TE on students' learning NP and the null hypothesis is accepted.

\section{FINDING AND DISCUSSION}

\section{The Comparison of Pretest Score between Experiment and Control Class}

The descriptive statistic of the pretest resulted in the followings. Experimental class consisted of 22 participants had the mean score of test 42.73, the maximum score 70 , the minimum score 30 and standard deviation 9.498. Meanwhile, the 22 participants in control class had the mean score of test of 41.36, the maximum score 61 , the minimum score 30 and standard deviation 8.522. Both classes were pre-tested with noun phrase with 20 items of multiple-choice questions.

Table 6. The Descriptive Statistic Analysis of the Pretest in experiment and control group

\begin{tabular}{lllll}
\hline N & Minimum & Maximum & Mean & Std. Deviation \\
\hline
\end{tabular}




\begin{tabular}{clllll}
\hline Pretest Experiment & 22 & 30 & 70 & 42.73 & 9.498 \\
Control & 22 & 30 & 60 & 41.36 & 8.522 \\
\hline
\end{tabular}

\section{The Comparison of Posttest Score between Experiment and Control Class}

The participants in experiment class with high achievement were 11 participants with the mean of post test score 75.00 with standard deviation 3.225, while the mean of control class, that also consisted of 11 participants, was 64.55 and the standard deviation was 4.803. Then, the total mean of both groups in the experimental group was 69.77 , and the total standard deviation was 6.676. Meanwhile, in control group, the mean of high achievers was 74.82 with the standard deviation of 3.125 , and mean of low achievers was 56.18 with the standard deviation of 6.161 . Then, the total mean of both initials in the control group were 65.50 with the standard deviation 10.663. The total mean of high achievers in both groups was 74.91 with standard deviation 3.100 , while the total mean of low achievers in both groups was 60.36 with standard deviation 6.884 .

Table 7. The Result of the Posttest in Experiment and Control Class

\begin{tabular}{llccl}
\hline Groups & Initial & Mean & Std. Deviation & $\mathrm{N}$ \\
\hline \multirow{4}{*}{ Experimental } & High achievers & 75.00 & 3.225 & 11 \\
& Low achievers & 64.55 & 4.803 & 11 \\
& Total & 69.77 & 6.676 & 22 \\
\hline \multirow{3}{*}{ Control } & High achievers & 74.82 & 3.125 & 11 \\
& Low achievers & 56.18 & 6.161 & 11 \\
& Total & 65.50 & 10.663 & 22 \\
\multirow{3}{*}{ Total } & High achievers & 74.91 & 3.100 & 22 \\
& Low achievers & 60.36 & 6.884 & 22 \\
& Total & 67.64 & 9.053 & 44 \\
\hline
\end{tabular}

\section{The Control and the Experimental Groups with High and Low Achievement students (Students' Initial Abilities)}

After getting the students' quiz score, the researchers classified the control and experimental groups into four groups; high achievers and low achievers in control group and high achievers and low achievers in experimental group. This division was conducted based on the students' score obtained from the quiz. From both groups that consisted of 44 students, in control group there were 11 students as high achievers, 11 students as low achievers. While in the experimental group there were 11 students as high achievers and 11 students as low achievers.

\section{Fulfillment of the Statistical Assumption}

There were two tests in statistical assumption used in this research namely homogeneity and normality. Both tests were analyzed using SPSS 20.

\section{a. Homogeneity Testing}


The Levene's Test was employed to test homogeneity of the students and collected data in this study. It was aimed at examining whether the students and the data from two groups namely the control and experimental groups equal to their entry behavior. The summary of the homogeneity testing was presented in the Table 8.

Table 8. The Result of Homogeneity Testing of Variance

\begin{tabular}{lllll}
\hline Factors & Levene Statistic & df1 & df2 & Sig. \\
\hline Groups & .524 & 1 & 42 & .473 \\
\hline Achievement & .062 & 1 & 42 & .872 \\
\hline
\end{tabular}

It is obvious that the observed significance of treatment in the control and the experimental group was .473, which is greater than .050. Thus, it was assumed that the two groups were homogeneous. Moreover, the result of the homogeneity testing on the English achievement was .872.

\section{b. Normality Testing}

The normality testing of this research used the Shapiro-Wilk test in order to decide whether the collected data came from the groups that had normal distribution. Table 9 provided the results of normality testing

Table 9. The Results of Normality Testing

\begin{tabular}{|c|c|c|c|c|}
\hline \multicolumn{5}{|c|}{ Normality Test } \\
\hline & \multirow[b]{2}{*}{ Initial } & \multicolumn{2}{|c|}{ Shapiro-Wilk } & \\
\hline & & Statistic & Df & Sig. \\
\hline \multirow{2}{*}{ Score } & High achiever & .876 & 22 & .010 \\
\hline & Low achiever & .928 & 22 & .113 \\
\hline
\end{tabular}

The results of the normality testing using Shapiro-Wilk test showed that the levels of significance of the high achievers was smaller than .050 (.010<.050), it means that the data in the control group was not normally distributed. Meanwhile, the normality testing for low achiever group showed that the significant level was .113, which was higher than .050. It indicates that the distribution of the data in low achievers was normal.

\section{The Result of the Hypothesis Testing}

The next step was testing hypothesis under this study. To verify different hypothesis, the researcher applied the Two-Way ANOVA. The result of the Two-way ANOVA was shown in the following table.

Table 10. The Statistical Compution Using Two-Way ANOVA

Dependent Variable: score

\begin{tabular}{llllll}
\hline Source & $\begin{array}{l}\text { Type III Sum of Df } \\
\text { Squares }\end{array}$ & Mean Square & F & Sig. \\
\hline Corrected Model & $2712.182^{\mathrm{a}}$ & 3 & 904.061 & 44.535 & .000 \\
Intercept & 201285.818 & 1 & 201285.818 & 9915.558 & .000 \\
Groups & 200.818 & 1 & 200.818 & 9.893 & .003
\end{tabular}




\begin{tabular}{llllll} 
Initial & 2327.273 & 1 & 2327.273 & 114.644 & .000 \\
groups * initial & 184.091 & 1 & 184.091 & 9.069 & .004 \\
Error & 812.000 & 40 & 20.300 & & \\
Total & 204810.000 & 44 & & \\
Corrected Total & 3524.182 & 43 & & \\
\hline a. R Squared $=.770$ (Adjusted R Squared $=.752)$ \\
\hline
\end{tabular}

\section{Hypothesis Testing 1}

In answering the first research question whether there is an effect of TE on students' learning NP, the researchers used Two Way ANOVA. The hypothesis can be answered as follows.

$\mathrm{H}_{0}=$ There is no effect of TE on students' learning NP.

$\mathrm{H}_{1}=$ There is an effect of TE on students' learning NP.

\begin{tabular}{llllll}
\multicolumn{5}{c}{ Table 11. The Result of Two Way ANOVA for Hypothesis 1} \\
\hline Source & $\begin{array}{l}\text { Type III Sum of Df } \\
\text { Squares }\end{array}$ & Mean Square & F & Sig. \\
\hline groups & 200.818 & 1 & 200.818 & 9.893 & .003 \\
\hline
\end{tabular}

The $\mathrm{F}$ between groups is 9.893 with the $p$-value (Sig.) .003 with the level of significance .050 . Thus, the $p$-value was smaller than $.050(.003<.050)$. It means that the null hypothesis is rejected (there is no effect of TE on students' learning NP) and the alternative hypothesis is accepted (there is an effect of TE on students' learning NP).

The result revealed that the TE had significant result on students' learning NP, shown in the $\mathrm{F}$ between groups which was 5.036 with the $p$ - value (Sig.) .003 with the level of significance .050 . Furthermore, the $p$-value was smaller than $.050(.003<.050)$, made a slight difference between two groups. Consequently, the null hypothesis was rejected and the alternative hypothesis was accepted. These results signified that there was significant effect of TE on students' learning NP. This finding was in line with Sarboland (2012), Ayiewbey (2013), and Torkabad \& Fazilatfar (2014) contending that TE helped students to increase their grammatical achievement.

Furthermore, TE aims at raising learners' attention to linguistic forms by rendering input perceptually and more saliently (Fotos \& Nassaji, 2011) by highlighting certain language forms/structures. Sarboland (2012) found that underlined and bold (TE) formats were effective than other formats in inducing the acquisition of the target form. Ayiewbey (2013) also stated that bold-faced and italicized letters increased learners' learning form, though bold faced displayed better performance than italicized form. Besides, TE also led the learners to pay more attention on the language features (Torkabada \& Fazilatfar, 2014). When the learners paid attention on that form, they were more attracted and focus on the target forms. The finding of this study also showed that TE was an effective focus on form technique, at least for learning NP, which is in line with Nahavandi \& Mukundan (2013) who supported the effectiveness of TE. 
In addition, TE made the learners more focused on learning NP, although the text led them to study more in language function and meaning rather than in form. This is supported by Ayiewbey (2013), arguing that TE made students notice and give more focus on the enhanced words in the text. The effectiveness of textual enhancement not only found in learning simple past tense, but also in the form of passive voice (Wicaksono, 2015) and learning verbal (Mehrdad, 2015). Wicaksono (2015) investigated the effect of textual enhancement on passive voice. He found that the students who were taught using enhanced instruction which was equipped with TE had significant and higher passive voice achievement than those students who were taught using explicit instruction only. In line with that, the study conducted by Mehrdad (2015) also showed that there was significant effect of TE on learning verbal in high school EFL male students.

\section{Hypothesis Testing 2}

The next was answering the second research question "Is there any significant different achievement between the high and low achievers in learning NP". The hypothesis was formulated as follows.

$\mathrm{H}_{0}=$ There is no significant different achievement between students with the high achievers and the low achivers in learning NP.

$\mathrm{H}_{1}=$ There is a significant different achievement between students with the high achievers and the low achivers in learning NP.

Table 12. The Result of Two Way ANOVA for Hypothesis 2

\begin{tabular}{llllll}
\hline Source & $\begin{array}{l}\text { Type III Sum of Df } \\
\text { Squares }\end{array}$ & Mean Square & F & Sig. \\
\hline Initial & 2327.273 & 1 & 2327.273 & 114.644 & .000 \\
\hline
\end{tabular}

The F between both groups is 114.644 with the $p$-value (Sig.) .000 between the initial (high and low achievers in both control and experimental groups). It is smaller than the significant level (Sig. .000>.050). Therefore, the result of the analysis rejected the null hypothesis and accepted the alternative hypothesis. It means that there is significant different achievement between the high and low achievers of control and experimental groups in learning NP.

It can be concluded that TE was effective in learning NP for students with high initial (high achievers). Thus, the students' level affect students' learning on NP. It is in line with Ghorbani \& Nezamoshari'e (2012), contending that there is significant difference between the high achievers in the experiment class regarding their grammar achievement. It means that the high achievers took advantages of learning than the lower achievers.

\section{Hypothesis Testing 3}

The last hypothesis testing was done to find the interaction between TE and the students' initial (high and low achievers). The null hypothesis resulted in no interaction 
between TE and students' initial (high and low achievers). Meanwhile, the alternative hypothesis of research question was that there was interaction between TE and students' initial (high and low achievers). To prove it, it was computed by using Two Way ANOVA. Table 13 provided the summary of statistical result of Two-Way ANOVA.

Table 13. The Result of Two Way ANOVA for Hypothesis 3

\begin{tabular}{llcccc}
\hline Source & $\begin{array}{l}\text { Type III Sum of df } \\
\text { Squares }\end{array}$ & Mean Square & F & Sig. \\
\hline groups * initial & 184.091 & 1 & 184.091 & 9.069 & .004 \\
\hline
\end{tabular}

The $\mathrm{F}$ is 9.069 with the $p$-value (Sig.) .004 between the initial (high and low achievers in both control and experimental groups). It was smaller than the significant level (Sig. $.004<.050$ ). The result of the analysis rejected the null hypothesis and accepted the alternative hypothesis. It means that there was interaction between TE and students' initial (high and low achivers) in learning NP. It can be concluded that the effectiveness of TE depends on students' initial. TE is more effective if it is applied for the high achievers. This finding was contradicted with Wicaksono (2015) who argued that TE was more effective if applied to low achievers than high achievers.

\section{CONCLUSION}

This research investigated TE on students' learning NP. Based on the research findings and discussion, there are three things to conclude from this study. First, there was significant difference in the students' achievement in comprehending NP between students who were taught by using TE (experimental group) and those who were taught by not using TE (control group). The students in the experimental group taught by TE outperformed the students in the control group taught by conventional technique. Second, there was significant different achievement between the high and the low achievers in control and experimental group in learning NP. Finally, there was an interaction between TE and students' initial (high and low achievers).

Based on the conclusions, the researchers propose two suggestions. First, regarding to the effectiveness of TE in students' learning NP on reading text, English lecturers are recommended to teach grammar through reading texts as an alternative technique to increase students' grammatical skill. TE can help lecturers to lead students to notice and focus on the target form on the course. Second, it is expected that the next researchers can carry out further research in relation with the research findings because TE can be used in various English grammatical aspects.

\section{REFERENCES}

Ary, D., Jacobs, L. C., Irvine, C. K. S., \& Walker, D. (2018). Introduction to Research in Education. Cengage Learning. 
Alsadhan, R. O. ( 2011). Effect of textual enhancement and explicit rule presentation on the noticing and acquisition of L2 grammatical structures: A meta-analysis. Colorado: Colorado State University Fort Collins.

Ayiewbey, S. (2013). The effects of textual enhancement on learning english past tense. World Applied Sciences Journal, 27(8): 1042-1048.

Collins, P. (2006). Grammar in TEFL: A critique of Indonesian high school textbooks. TEFLIN Journal, 17(1), 01-10.

Ellis, R. (1994). The Study of Second Language Acquisition. New York: Oxford University Press.

Ghorbani, M. R \& Nezamoshari'e, M. (2012). Cooperative learning Boost EFL students' grammar achievement. Theory and Practice in Language Studies, 2(7), 1465-1471

Han, Z., Park, E. S., \& Combs, C. (2008). Textual enhancement of input: Issues and possibilities. Applied linguistics, 29(4), 597-618.

Harmer, J. ( 2007). The Practice of English Language Teaching (Fourth Ed.) Harlow: Longman.

Krashen, S. (1982). Priciples and Practices in Second language Acquisition. Oxford: Permagon.

Larsen-Freeman, D. (2007). Techniques and Principles in Language Teaching. Oxford: Oxford University Press.

Latief, M. A. (2012). Research Methods on Language Learning: An Introduction. Malang: Universitas Negeri Malang.

Long, M. H. (1985). Input and second language acquisition theory. Input in Second Language Acquisition, 377-393.

Long, M. \& Robinson, P. (1998). Focus on Form: Theory, Research and Practice. In C. Doughty \& J. Williams (Eds), Focus on form in classroom second language acquisition (pp. 13-41). Cambridge: Cambridge University Press.

Mehrdad, G. (2015). The effect of textual input enhancement on learning verbals in highschool EFL male students Nika Tahmouresi. International Journal of Education Investigations, 2 (8).

Nahavandi, N. \& Mukundan, J . (2013). The impact of textual input enhancement and explicit rule presentation on Iranian elementary EFL learners' intake of simple past tense. English Language Teaching, 6(1)

Nassaji, H., \& Fotos, S. S. (2011). Teaching grammar in second language classrooms: Integrating form-focused instruction in communicative context. Routledge.

Sarboland, E. (2012). Different textual enhancement formats and the intake of English past simple tense. International Journal of Linguistics, 4(2), 459-474.

Sheen, R. (2002). Focus on form' and 'focus on forms. ELT journal, 56(3), 303-305.

Smith, M. S. (1993). Input enhancement in instructed SLA: Theoretical bases. Studies in second language acquisition, 15(2), 165-179. 
Torkabada, M. G \& Fazilatfar, A. M. (2014). Textual enhancement and input processing effects on the intake of present and past simple tenses. Procedia-Social and Behavioral Sciences 98, $562-571$.

Wicaksono, J. A. (2016). The Effect of Textual Enhancement as Implicit Instruction in Teaching Passive Voice on The Eleventh Graders' Passive Voice Achievement. DISERTASI dan TESIS Program Pascasarjana UM. 